\title{
European Schoolnet - bringing the world into the classroom
}

\author{
Jan Hylén \\ Executive Secretary, Committee of European Schoolnet, Ministry of Education and Science, SE- \\ 10333 Stockholm, Sweden. \\ jan.hylen@education.ministry.se
}

\begin{abstract}
The paper will deal with the two most important challenges facing education today: the increasing globalisation and permeation of ICT of our society. To meet these two challenges eighteen Ministries of Education in Europe joined forces in 1997 to create a common Internet platform, called the European Schoolnet. The objectives were to find synergies between national initiatives, to promote the use of ICT in education and to facilitate co-operation between schools in Europe.

Now the time has come to ask not only what ICT can do for schools, but also what ICT does to schools? How does the influence of ICT on society change the role of the school and the teacher? Two scenarios will be outlined: 1. the diminishing school - a reduction of the schools and the role of the teacher and a growth in home schooling; 2 . the expanding school - where the need for lifelong learning puts the school in the centre of the development and changes the role of the teacher to become a guide to learning in schools and companies.

To help to transform the second scenario into reality, the European Schoolnet must in the coming year focus its attention on four areas: collaboration, communities, content and commerce. These four "c's" and their implication for the development of the European Schoolnet and the European schools using the Internet will be further elaborated in the paper.
\end{abstract}

Keywords: Communications, innovation, networks, policy

The original version of this chapter was revised: The copyright line was incorrect. This has been corrected. The Erratum to this chapter is available at DOI: 10.1007/978-0-387-35403-3_29 


\section{INTRODUCTION}

The information and communications technology (ICT) society emerging today is a change as great as the transition to an industrial society. It influences all areas in society, and we are in the very middle of this process. No one can know with certainty what central development routes will become apparent. Perhaps it is possible to compare the importance of ICT today with the role of electricity in industrial society. From being a knowledge area for technicians, ICT has now become an everyday tool in an ever-increasing number of areas.

This technology has already to a great extent invaded many work places, and now it is beginning to penetrate education and commerce, and soon in cars and homes as well.

The growth of the ICT society is characterised by three things:

Knowledge: The value of knowledge and competence is continuously increasing. "The knowledge society" is in many respects a reality. New jobs in working life put much higher demands on education than earlier.

The old division between white and blue-collar work is no longer relevant. Today, all citizens need knowledge and skills in general subjects such as reading and writing, mathematics, foreign languages and social studies.

Networks: Networks are becoming increasingly prominent as the central organisational structure in and ICT-rich society. This is impacting industry and working life, as well as other areas. For example, in public administration we can see "mergers" in combination with decentralised activities and partnerships.

In schools, the traditional industrial way of organising teaching confronts new challenges, which create a need for change and development of approaches to teaching. The ICT society does not lead to a situation where all young persons need to become programmers. However, it does mean that all persons need to be prepared and have the ICT competencies needed to reprogram themselves in a constantly evolving working life.

For the European economy to develop positively and new jobs to be created, flexibility on the labour market is important. This can be achieved if many, preferably all, have the ability to adjust and develop in order to confront the new challenges posed by a working life that is rapidly changing. This, in turn, imposes high demands on basic education, lifelong learning and self-confidence. 
Essentially, the school is confronted by a number of new and much more difficult tasks than ever before. Pupils should acquire more knowledge and more advanced knowledge than before. They should be familiar with the emerging technologies. They should learn to work both independently and together with others. They should develop self-confidence and lay the foundations for lifelong learning.

\section{THE EUROPEAN SCHOOLNET}

Paramount among the many challenges facing education today is the need for schools to prepare young people for the emerging information society. This has been realised throughout the European educational sector. This understanding was also the background for the informal meeting of European Council of Education Ministers in March 1997, to endorse the initiative to set up a network of networks, comprised of national, regional and other Web-based schoolnets, as a framework for co-operation and mutual support, called the European Schoolnet.

The European Schoolnet (EUN) was given four main goals:

1. to facilitate collaboration between schools in Europe,

2. to offer a range of high quality educational content and teaching services representing a European added-value,

3. to provide opportunities for professional development for teachers, and

4. to enhance co-operation at a European level among national education authorities, universities and industry to develop ICT in schools.

The EUN is much more than a website. It is an online campus where all those concerned with education in Europe will find information, locate resources, and meet people in a comprehensive service for schools and colleges. It is a human network and not just a technical one.

Currently 20 Ministries of Education in Europe take part in this joint venture. It is a framework for collaboration between the Ministries. There are separate arrangements for editors responsible for content in the national networks and for those providing the technical infrastructure. There are networks for school managers, for subject matter teachers, and for innovative schools.

Every country in the EUN Consortium has nominated a national network on the Internet, and there are direct links to each of these from the European Schoolnet website. These "Partner Networks" also deliver content with an added European value. The national networks are responsible for the translation of many sections of the website into their own languages.

Through its multi-lingual website the European Schoolnet provides high quality tools, content, and services. These assist teachers and learners to 
work together and to benefit from the Europe-wide range of resources and contacts which ICT brings within reach for every school. At the same time, the development of ICT capability among teachers and learners is actively encouraged.

The EUN has a simple intuitive structure. The four main areas of the network's activity (resources, innovation, school collaboration, and teacher development) are easy to locate from any point of the site. Pages aimed at teachers and pupils provide links to relevant updated content each week. There are weekly updates of relevant news and information in 10 different languages as well as free electronic newsletters. The framework and tools needed to run an international school project can be found, enabling any teacher to undertake a project supported by ICT.

\section{EUN WEBSITE}

Although the website is still very much under construction, it is widely used and appreciated by schools. According to statistics available so far, the number of visitors and downloaded pages has increased by 7.5 times from the fall 1998 to the fall 1999. On the peak month so far, almost 880,000 pages were downloaded. The five countries using the EUN the most so far are Sweden, Italy, Spain, Denmark and the United Kingdom.

Four evaluations with a more qualitative approach have been launched. These include an overall evaluation of the EUN website, a technical evaluation of the platform, a user requirement evaluation by schools, and an in-depth interview of national networks. Both external and internal reviewers are used. An interim evaluation report from September 1999 points out challenges such as creating a coherent vision to develop bottom-up projects with the many partners. The report also notes that the initiative has a huge potential and holds many promises that still have to be exploited.

\section{RESULTS}

It is fair to say that the European Schoolnet initiative has been successful so far. Together with national initiatives in almost every European country to develop the use of ICT in education, the EUN has stimulated European collaboration and the enhanced and enriched the utilisation of ICT in schools.

As is very clearly shown from the massive introduction of ICT in education, schools always operate within a context. The school is always a part of and affected by the surrounding society. From time to time it is 
important to try to have a view on how this larger context in the more long term might effect the schools. The time has come to ask not only what ICT can do for schools, but also how does the influence of ICT on society change the role of the school and the teacher?

Two different scenarios will very briefly be outlined:

1. the diminishing school - a reduction of the schools and the role of the teacher and a growth in home schooling; and

2. the expanding school - where the need for lifelong learning puts the school in the centre of the development and changes the role of the teacher to become a guide to learning in schools.

Two factors are of importance. One is, of course, the rapid development in ICT and particularly better and faster connections to the Internet. Soon we will have high-speed connections or information highways both in our homes and in our workplaces. At least in Sweden this will be the case in a 57 year perspective as a result of massive governmental investments in the years to come.

The other factor is the probable raise in demand for education and training, both from individuals, companies and public administration, as a result from the new economy and society that is emerging. The need for lifelong learning is more and more evident.

Most probably both the demand and supply of what so far has been called "distance education" will grow rapidly - i.e., online courses, selfinstructive teaching material, "edutainment", etc. The formal education system will find itself placed in a much more competitive situation than ever before. This challenge to the educational system can be handled in two ways:

Method 1: If the formal education system fails to meet the competition and adapt itself to the new situation, we might end up with much more of private supply and demand for education where both companies and families buy education on the Internet from the best and cheapest supplier, private or public, domestic or international. This is already happening to schools in some countries and in the higher education sector in many nations.

If more and more parents believe that on-line education at home is a better alternative than the formal school system, such a development would drastically change and reduce the role of the school. Even if the politicians try to keep the mandatory school, the formal education system would be reduced in importance in the eyes of parents and pupils, and soon also in the eyes of policy makers and teachers. It would be reduced to a second best alternative.

Method 2: On the other hand, if the education system manages to adapt accordingly and succeed in transforming itself to a centre for learning not only for students but also for companies, the opposite development could take place. The role of the school in the community could be that of a centre for lifelong learning. 
For this to happen a lot of changes have to come about, also in the role of the teacher, but foremost in the philosophy and understanding of what a school is or could be. Policy makers, school managers and teachers must start to look at the school as a resource centre in the community where it is situated. Schools should start to work together with distance education suppliers and local companies, with local teachers as tutors and facilitators for learning. The policy makers should encourage schools to develop, to be prepared for a new era and to try to be pro-active instead of looking at themselves as victims in an immovable process.

So far many have talked about the changing role of the teacher in the "information age", but it is ample time to start thinking of the role of the policy makers and school managers in this new era. How can they promote and facilitate the necessary changes? What new ways of managing and perhaps also financing schools do we need? What role do we want the formal education system to have in our future society? Also more concrete questions, as how to recognise skills learned outside school, need to be raised. How should we monitor learning for students engaged in virtual schooling both in school and out of school? These are the kind of questions those of us who still believe that the formal education system could be a guarantee for quality and equity in learning also in the future must start to ask ourselves.

Of course these questions are the responsibility and privilege for every country to deal with in the way they believe is the best. But 20 of the European countries have chosen to work together within the framework of the European Schoolnet as one way to develop ICT in their national education systems. The European Schoolnet is not only a web service for schools, but also a framework for co-operation between ministries. Seminars on national ICT strategies, workshops and exchange of experiences between ministers and key players from each country are also an important parts of the EUN. Therefore also the EUN has to develop a strategy to deal with this coming situation.

\section{NECESSARY CONDITIONS}

What is needed in order to give a contribution to transformation of the second scenario into reality is to create services, frameworks for development on an individual level for the teacher and for schools, and possibilities to explore the opportunities for new ways of teaching and learning created by the rapid technological development. The European Schoolnet must in the coming year focus its attention on four areas: collaboration, content, communities and commerce. These four "c's" and 
their implications could be a first step in the right direction. They all constitute services that are best provided by public authorities and not commercial providers.

Collaboration - School collaboration have from the very start been an important part of EUN. Collaboration between pupils and teachers, in subject related or cross curricula projects, to learn from each other, to make use of each other strengths, to support the use of foreign languages. The EUN should continue to provide content and services which enables teachers with varying experiences to plan, launch and complete projects using ICT. The services should be as automated as much as possible, with users adding content themselves, like forums, partner-finding tools and publishing tools.

Content - Throughout Europe there are many networks and projects funded by national Ministries of Education and the EU Commission. The EUN should make it easy to locate the information and resources which these initiatives have produced. They should be free, relevant, of good quality, easily accessible and easy to find. A search engine should allow pupils and teachers to make multilingual searches across websites exclusively selected by the EUN partners for their relevant educational and cultural content.

Communities - Collaboration activities should be encouraged to develop into learning communities. They could involve individual teachers, schools, researchers and teacher trainers, and officials and policy makers. The most promising development would be teachers working together, developing their skills, their contacts with colleagues in their subject field or area of interest. Schools should be encouraged to form communities centred around local strategies for organisational and pedagogical development with ICT. Schools could work with teacher training institutions involving both teachers, teacher trainers, teacher students and researchers.

Commerce - The EUN could make a unique contribution by offering a possibility for teacher-to-teacher e-commerce, were products developed by teachers for teachers are marketed and sold. The focus should not be to earn big money, rather to stimulate teachers to exchange material they have already developed, to get recognition of the value of their work, but also to encourage them to explore the opportunities offered by ICT. Such a service could also function as a test pilot in e-commerce in the education sector for national agencies and ministries. 
The role of the European Schoolnet could not only be to develop these services on a European level but also to stimulate and act as a test case for national developments. The ultimate value of the EUN lies in offering services and a framework to create added value to the national networks and to help them to establish the public school networks as a competitive alternative to commercial products. If this could be done within the four areas briefly outlined above, the European Schoolnet would continue to be a very valuable contribution to the development of the schools in Europe in the years to come.

\section{BIOGRAPHY}

Jan Hylén is currently the Executive Secretary for the Committee on European Schoolnet within the Swedish Ministry of Education and Science. $\mathrm{He}$ received his Bachelor of Arts from University of Stockholm 1984 in Political Science, Philosophy and Economics and his Ph.D. from University of Stockholm in 1991 in Political Science. In 1986-87 Jan Hylén acted as secretary to the Nordic UNESCO Commissions in their evaluation of Minespol UNESCO research policy conferences. Dr Hylén was the head of the Research Department of the National Agency for Education in Sweden until 1995. The National Agency for Education is responsible for supervising and evaluating the Swedish school system. During1995-1998 he served as special advisor to the Minister of Schools and Adult Education. 